\title{
Utilization of Space-Borne Imagery for Lithologic Mapping: A Case Study From Um Had Area, Central Eastern Desert, Egypt
}

\author{
Nedal Qaoud ${ }^{1}$ \\ ${ }^{1}$ Geology Department, Faculty of Science, Al-Azhar University, Gaza, Palestine \\ Correspondence: Nedal Qaoud, Geology Department, Faculty of Science, Al-Azhar University, Gaza, Palestine. \\ E-mail: nedalqaoud@hotmail.com
}

Received: April 1, 2014 Accepted: April 20, 2014 Online Published: April 30, 2014

doi:10.5539/jgg.v6n2p113 URL: http://dx.doi.org/10.5539/jgg.v6n2p113

\begin{abstract}
Remote sensing data are used to discriminate between the different lithologies covering the Um Had area, Central Eastern Desert of Egypt. Image processing techniques applied to the Enhanced Thematic Mapper $(\mathrm{ETM}+)$ data are used for mapping and discriminating the different basement lithologies of Um Had area. Principal component analysis (PCA), minimum noise fraction (MNF) transform and band rationing techniques provide efficient data for lithological mapping. The study area is underlain by gneisses, ophiolitic melange assemblage (talc-serpentinite, metagabbro, metabasalt), granitic rocks, Dokhan volcanics, Hammamat sediments and felsites. The resulting gray-scale PC2, PC3 and PC4 images are best to clearly discriminate the Hammamat sediments, amphibolites and talc-serpentinites, respectively. The gray-scale MNF3 and MNF4 images easily discriminate the felsites and talc-serpentinites, respectively. The band ratio 5/7 and 4/5 images are able to delineate the talc-serpentinites and Hammamat sediments, respectively. Information collected from gray-scale and false color composite images led to generation of detailed lithologic map of Um Had area.
\end{abstract}

Keywords: lithologic mapping, band ratio, minimum noise fraction, Um Had area, Egypt

\section{Introduction}

Remote sensing sensors can provide detailed information on the lithologies comprising the Earth's surface. The recent developments in sensor technology have enabled remote sensing to become an increasingly important tool for mapping lithologies, structures and ore deposits, particularly for remote areas with little or no access, or areas that lack detailed topographic or geologic base maps. During the past few decades, remote sensing data have been analyzed using several digital image processing techniques (e.g., image enhancement, fusion, band rationing, and principal component transformation) to carry out lithologic mapping and to identify mineral deposits in arid and semi-arid environments (e.g., Sultan et al., 1986; Chavez, 1989; Abrams \& Hook, 1995; Sabins, 1997; Kusky \& Ramadan, 2002; Gupta, 2003; Mars \& Rowan, 2006; Gad \& Kusky, 2007; Youssef et al., 2009; Madani \& Emam 2011; Ali-Bik et al., 2012; Zoheir \& Emam, 2012, 2013). The multispectral sensors such as the Thematic Mapper (TM) and the Enhanced Thematic Mapper plus (ETM+) mounted on the Landsat satellites are the most used in lithologic mapping and mineral exploration (Salem et al., 2011). Landsat Thematic Mapper (TM) band ratios (5/7, 5/1,5/4*3/4) in RGB coloring mode have been used for mapping serpentinites in the Eastern Desert of Egypt (Sultan et al., 1986). They concluded that these band ratios can be used to distinguish serpentinites from the surrounding mafic rocks with high amounts of magnetite and hydroxyl-bearing minerals in arid regions. Gad and Kusky (2006) used the false color combinations of ETM+ band ratios (5/3, 5/1, $7 / 5)$ and $(7 / 5,5 / 4,3 / 1)$ for mapping serpentinites in Barramiya area in the Central Eastern Desert of Egypt. They suggested that these band ratios can be used as well as the Sultan et al. (1986) band ratios for mapping serpentinites in the Eastern Desert of Egypt. Moreover, Youssef et al. (2009) used the false color combination of ETM+ band ratios $(5 / 3,5 / 1,7 / 5)$ to discriminate between different granitic phases of the Kadabora granitic intrusion, Central Eastern Desert of Egypt, and its surrounding environs.

The present paper deals with lithological mapping using remotely sensed Landsat Enhanced Thematic Mapper Plus $(\mathrm{ETM}+)$ data. Principal component analysis, minimum noise fraction transform and band ratio techniques are applied to determine the main spectral characteristics of ophiolitic mélange assemblage, granitic rocks, Dokhan volcanics and Hammamat sediments of Um Had area, Central Eastern Desert of Egypt (Figure 1), on the $\mathrm{ETM}+$ images. 


\section{Methodology}

Landsat-7 ETM+ sensor has eight broad spectral bands, three visible bands $(1,2$, and 3$)$, one near infrared band (4) and two short-wave infrared bands ( 5 and 7). These bands have a spatial resolution of $30 \times 30 \mathrm{~m}$. The thermal infrared band (6) has a $60 \times 60 \mathrm{~m}$ spatial resolution, while the panchromatic band (8) has $15 \times 15 \mathrm{~m}$ spatial resolution. For lithologic mapping and discrimination between the different rock units at Um Had area, image subset of ETM+ data (174/42 path/row, acquisition date 09/03/2005) have been processed using the ENVI 4.5 (ENVI® image processing and analysis software, from ITT Visual Information Solutions). The image processing techniques such as PCA, MNF and band ratios were applied to achieve the main purpose of the present study.

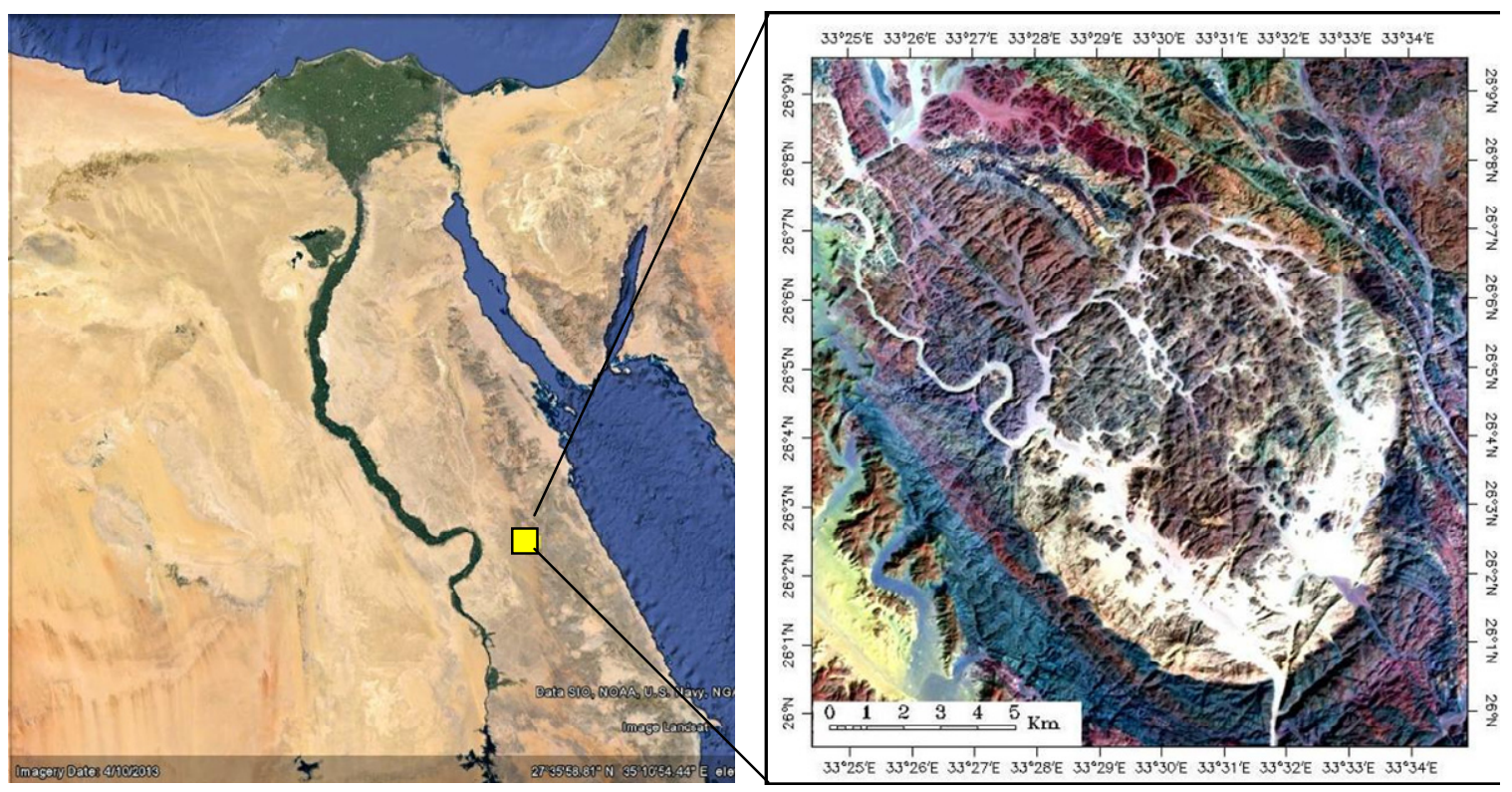

Figure 1. Location map of Um Had area, Central Eastern Desert of Egypt

\section{Test Site Description}

The Eastern Desert of Egypt constitutes the northwestern end of the Nubian segment of the Arabian-Nubian Shield (ANS) that formed through a series of subduction, accretion and crustal thickening processes during the Neoproterozoic Pan-African Orogeny (Engel et al., 1980; Stern, 1994; Johnson \& Woldehaimanot, 2003). The most prominent feature of the basement rocks in the Eastern Desert is the presence of dismembered ophiolites, metamorphosed volcano-sedimentary successions and calc-alkaline I-type intrusive complexes. The final stage (between 614 and $550 \mathrm{Ma}$ ) in the Pan-African crustal evolution in Egypt was characterized by the eruption of Krich volcanic rocks (Dokhan volcanics) and emplacement of shallow level felsic intrusions (Egyptian Younger Granites). Consequently, the Eastern Desert of Egypt is almost exclusively built up of: 1) island arc assemblage (850-614 Ma; Kröner et al.,1992; Stern, 1981; Stern \& Hedge, 1985); 2) ophiolitic sequences (810-730 Ma; Kröner et al., 1992); 3) older granitoids (750-610 Ma; Hashad, 1980; Mogahzi, 1999; Stern \& Hedge, 1985); 4) Dokhan volcanic suite (630-580 Ma; Stern \& Hedge, 1985; Abdel-Rahman \& Doig, 1987; Stern \& Gottfried, 1986; Wilde \& Youssef, 2000; Breitkreuz et al., 2010); 5) molasse-type Hammamat sediments (610-585 Ma; Wilde \& Youssef, 2002; Willis et al., 1988), and 6) younger granitoids (610-550 Ma; Stern \& Hedge, 1985; Mogahzi, 1999; Moussa et al., 2008).

Um Had area is occupied mainly by ophiolitic mélange assemblage represented by serpentinites, metagabbro, and metabasalt. The ophiolitic mélange rocks are intruded by granitic rocks, and overlain by Hammamat sediments (Figure 2). The ophiolitic mélange rocks are composed mainly of serpentinites, metagabbros and metabasalts. The ophiolitic mélange assemblage is intruded by post-emplacement younger granites and later basic to acidic dykes that cut all of the ophiolite units. The Um Had area contains a large elliptical structure trending northwest outlining a core of medium- to high-grade partly gneissic rocks enclosed by a domed thick mylonitic shear zone (e.g., Fowler, 2001). The core is up-heaved by the Um Had granitoid intrusion. The latter and its equivalents scattered throughout the Egyptian Eastern Desert was emplaced during Pan-African orogeny. These granitoids are referred to as late- to post-orogenic calc-alkaline to transitional A-type granitoids, 
interpreted by Black and Liegeois (1993) as being the result of delamination of the continental lithospheric mantle following the tectonic collisions of East and West Gondwana. These granitoids are characterised by unfoliated, small, nearly circular to elongate epizonal plutons with sharp intrusive contacts. The southern, SW and SE contacts of this intrusion dip generally at moderate angles outwards, whereas, the western and eastern contacts are steep and associated with syn-intrusion faulting. On the other hand, the northern edge is defined by the northernmost significant dykes cropping out along Wadi Shegila. To the west and south of Um Had intrusion, the Dokhan volcanics and Hammamat sediments crop out.

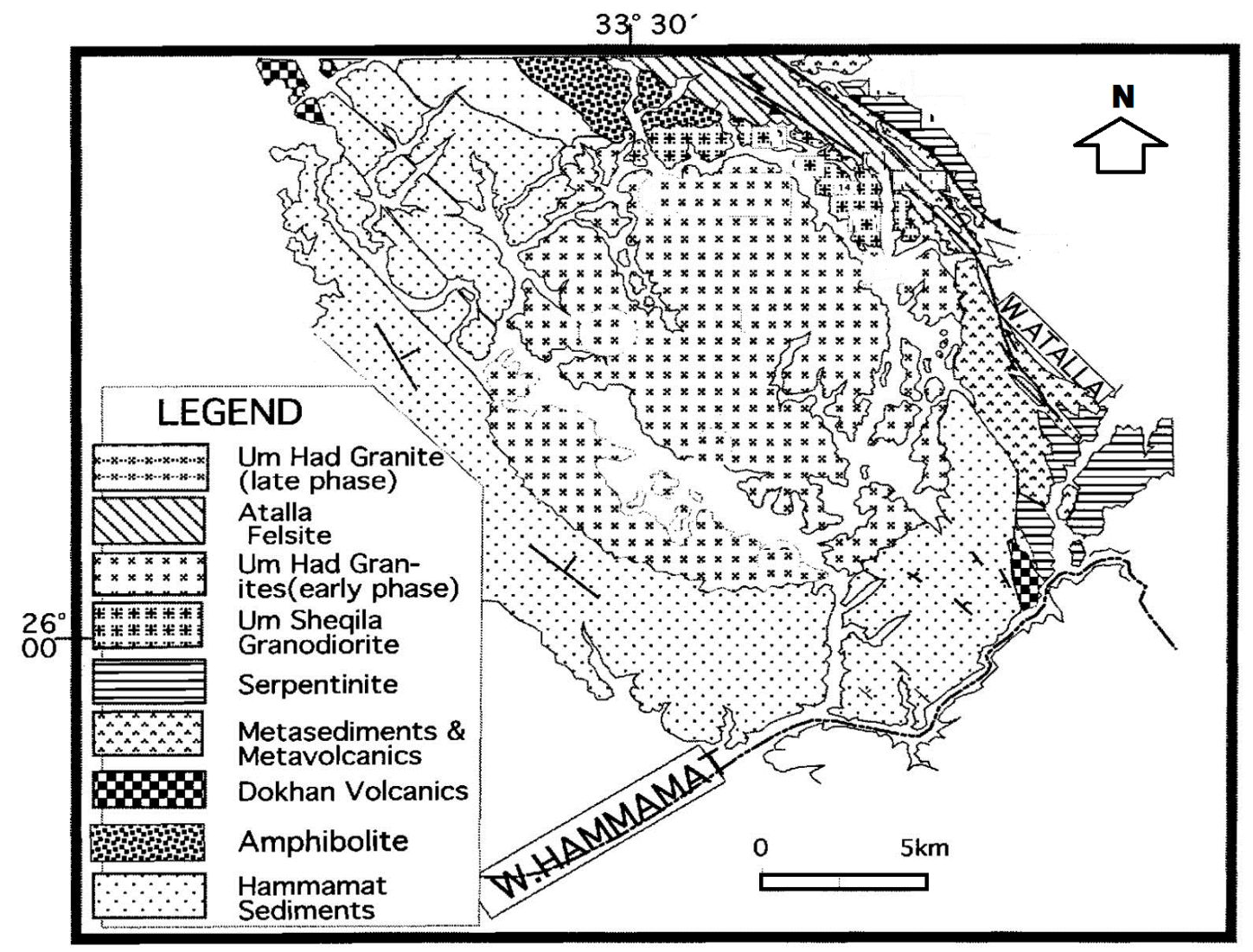

Figure 2. Geological map of the Urn Had granitoid intrusion, Central Eastern Desert of Egypt

\section{Image Processing of ETM+ Data}

Several processing techniques using the six visible-near infrared (VNIR) and shortwave infrared (SWIR) ETM+ bands have been proposed to discriminate lithologies and to highlight the abundance of minerals or natural resources (e.g., Kaufmann, 1988; Madani et al., 2003, Ramadan \& Kotny, 2004; Al Rawashdeh et al., 2006; Dogan, 2008, Rajesh, 2008; Madani, 2009; Shalaby et al., 2010, Abou Elmagd et al., 2013). The current contribution aims to apply three processing techniques (PCA, MNF and band ratios) to differentiate between different lithologies at Um Had area.

\subsection{Principal Component Analysis (PCA)}

The principal component analysis is the image processing technique commonly used for analysis of correlated multidimensional data. It is multivariate statistical method used to compress multispectral data sets by calculating a new coordinate system and redistribute data onto a new set of axes in multidimensional space (Drury, 1987; Gupta, 1991). The PCA may be carried out for multispectral data sets consisting of any number of bands to produce sets of perpendicular PC-axes; each PC-axis has new pixel values (Moik, 1980). So, one digital PC-image for each PC-axis can be made and the obtained PC-images may be displayed separately as single stretched PC-images or used as a component in color composite PC-image. According to Singh and Harrison (1985), two types of principal component analysis can be distinguished, depending on the procedure by which the principal components are mathematically calculated. The un-standardized PCA uses the covariance matrix 
obtained from the input multispectral data, whereas the standardized PCA uses the correlation coefficients instead of covariance matrices for calculating the principal components. The principal component transformation has several advantages, where most of the variance in a multispectral data set is compressed into one or two PCimages. Moreover, noise may be relegated to the less correlated PC-images and the spectral differences between materials may be more apparent in PC-images than in individual bands (Sabins, 1997). In the present study, the PCA technique has been applied on the six VNIR and SWIR ETM+ bands. The resultant gray-scale PC2-image is best to discriminate the Hammamat sediments with bright tone and the amphibolites with dark tone (Figure 3a). The PC3 image (Figure 3b) successes to delineate the amphibolites with bright tone, meanwhile the PC4 image (Figure 3c) is able to distinguish the serpentinites with bright tone and the gneisses with dark tone. In the three PC images, Um Had granites appear with gray tone. The false color combination of PC4, PC2 and PC3 was created in red, green and blue channels, respectively (Figure 3d). This FCC PC image is able to distinguish between most of the rock units at Um Had area. The Um had pink granite and granodiorite are exhibit olive green and bluish green signature, respectively. The talc-serpentinites have yellowish and orange image signature, while gneisses show dark blue signature. On the other hand, Hammamat sediments exhibit pale green and cyan image signature, while Dokhan volcanics have bluish signature. The amphibolites and felsites show pinkish blue and lemon image signatures, respectively. The siliceous sedimentary cover, quartz veins and mélange materials exhibit reddish image signature.

\subsection{Minimum Noise Fraction (MNF)}

The minimum noise fraction (MNF) algorithm is applied to reduce spectral and spatial complexity of the data. The MNF processing reduces the spectral dimensionality of data by locating linear combinations of bands that match the inherent dimensionality of the data. So, the (MNF) transform is used to determine the inherent dimensionality of image data, to segregate noise in the data, and to reduce the computational requirements for subsequent processing (Boardman \& Kruse, 1994). The MNF transform as modified from Green et al. (1988) is essentially two cascaded Principal Component transformations. The first transformation, based on an estimated noise covariance matrix, decorrelates and rescales the noise in the data. This first step results in transformed data in which the noise has unit variance and no band-to-band correlations. The second step is a standard Principal Components transformation of the noise-whitened data. The MNF transform technique was applied on the nonthermal six ETM+ bands. On the gray-scale MNF1 image (Figure 4a), the Hammamat sediments show dark gray tone, while the MNF3 image (Figure $4 \mathrm{~b}$ ) discriminates clearly the amphibolites with dark gray tone and felsites with bright tone. On the other hand, the MNF4 image is best to delineate the talc-serpentinites with bright tone and the gneissose rocks with dark gray tone (Figure 4c). The false color composite MNF-image was generated from combination of MNF4, MNF1 and MNF3 in red, green and blue channels respectively (Figure 4d). This image clearly differentiates between the ophiolitic mélange rocks (pinkish), Hammamat sediments (purple), Dokhan volcanics (dark green), and gneisses (bluish green). The Um Had pink granites (lemon) are easily distinguished from the granodiorites (blue). Also, felsites exhibit light cyan image signature, whereas the amphibolites show reddish signature.

\subsection{Band Ratios (BR)}

Band rationing is an extremely useful processing technique for enhancing features in remote sensing images. It has been used for many years in remote sensing to effectively display spectral variations and extract valuable information. Drury (1993) prepared simply the band ratio by dividing the digital number (DN) values of each pixel in one band by the corresponding DN values of another band. Since ratios seldom fall outside the range $0.25-4.0$, in order to display the ratio the values must be re-scaled to 0-255 range. Band ratio technique enhances the objects based on the differences in reflectivity between the numerator and denominator spectral bands. Frei and Jutz (1989) mentioned that there are some effective factors controlling the lithological mapping using remote sensing techniques including the increased concentration of minerals relative to the background in the locality and the mineral assemblage characteristics. The main advantage of band ratio images is that they used to reduce the variable effects of illumination condition, thus suppressing of the expression of topography (Crane, 1971). Also, band ratio is a data compressive nature, thus band ratio images are less correlated and chromatically enhanced than original bands.

Several researchers dealt with the lithological mapping using band ratio images which was applied on Thematic Mapper images (e.g., Abrams et al., 1983; Kaufmann, 1988; Abdelsalam \& Stern, 1999; Sultan et al., 1986; Kusky \& Ramadan, 2002; Gad, 2002; Gad \& Kusky, 2006; Frei \& Jutz, 1989; Sabins, 1999). In the current contribution, the band ratios (5/7), (4/5), (3/1), (5/1), (5/4) and (3/4) were applied on the ETM+ subset covering Um Had area. The band ratio 5/7 image (Figure 5a) clearly discriminates the talc-serpentinites (bright tone) and gneissose rocks (dark gray tone). On the other hand, the band ratio $4 / 5$ image (Figure $5 b$ ) is able to identify the 
amphibolites (dark tone) and Hammamat sediments (bright tone). The band ratios 5/7, 4/5 and 3/1 were merged together in red, green and blue channels (Figure 5c). This FCC band ratio image differentiates between the talcserpentinites (yellow and orange), amphibolites (dark red), gneisses (greenish blue), Hammamat sediments (lemon), Dokhan volcanics (dark green), Um Had granites (bluish and light green) and the siliceous rocks (pink). Moreover, the FCC band ratio (5/7, 5/1,5/4*3/4) image was processed (Figure 5d) and clearly discriminates the ophiolitic mélange rocks (pinkish), Hammamat sediments (reddish), Um Had pink granites (pale green), granodiorites (bluish green) and felsites (cyan). Integration of all information extracted from the processed ETM+ images resulted in generation of a new detailed lithologic map for Um Had area (Figure 6). This map shows clearly the spatial distribution of different varieties of the ophiolitic mélange assemblage, granitic rocks, Hammamat sediments, Dokhan volcanics and felsites.

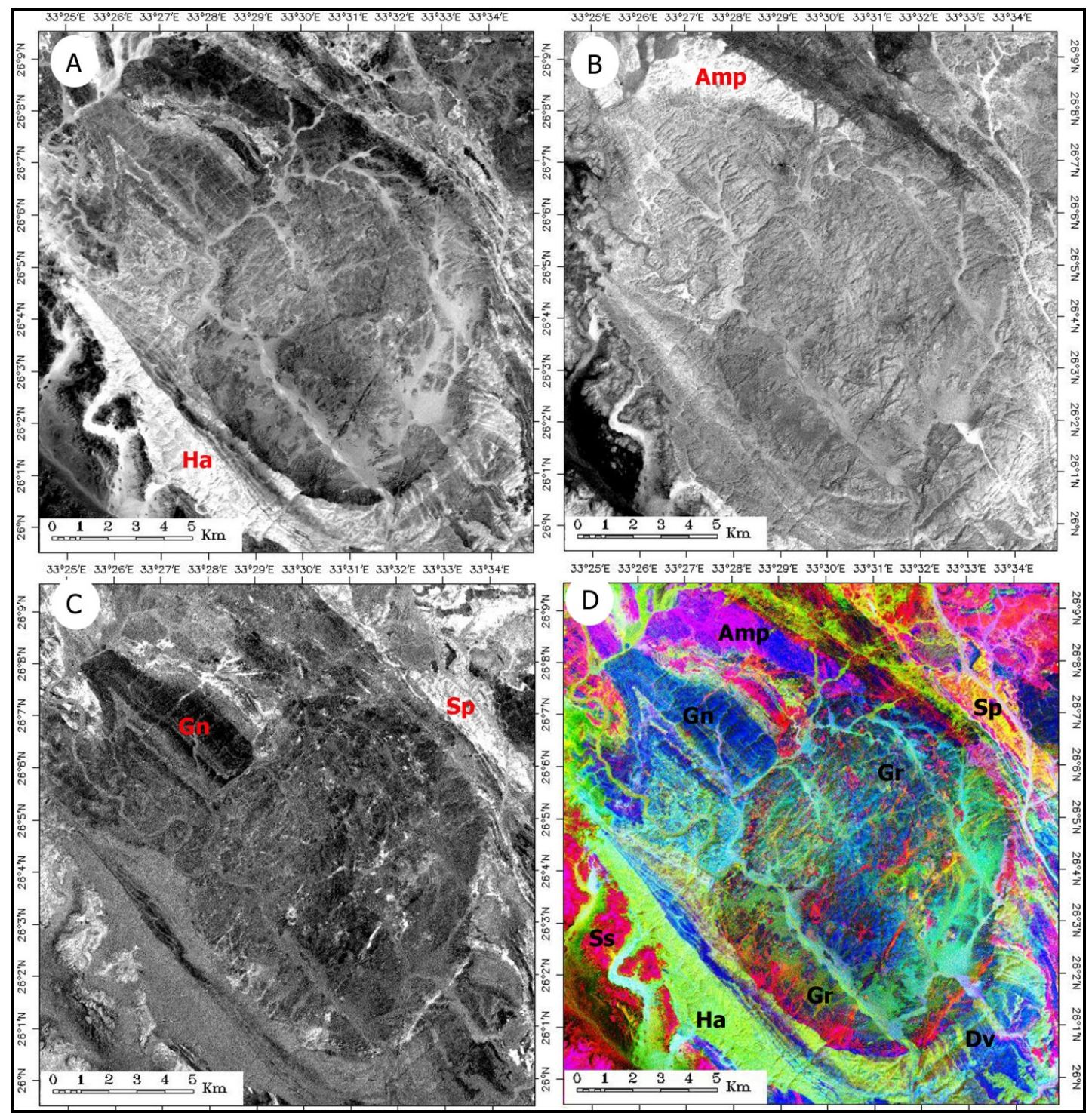

Figure 3. A) gray-scale PC2 image shows the Hammamt sediments (Ha) with bright tone, B) gray-scale PC3 image shows the amphibolites (Amp) with bright tone, C) gray-scale PC4 image shows the gneisses (Gn) with dark gray tone and the serpentinites (Sp) with bright tone, D) False color RGB combination of (PC4, PC2, PC3) discriminates clearly between the different rock units 


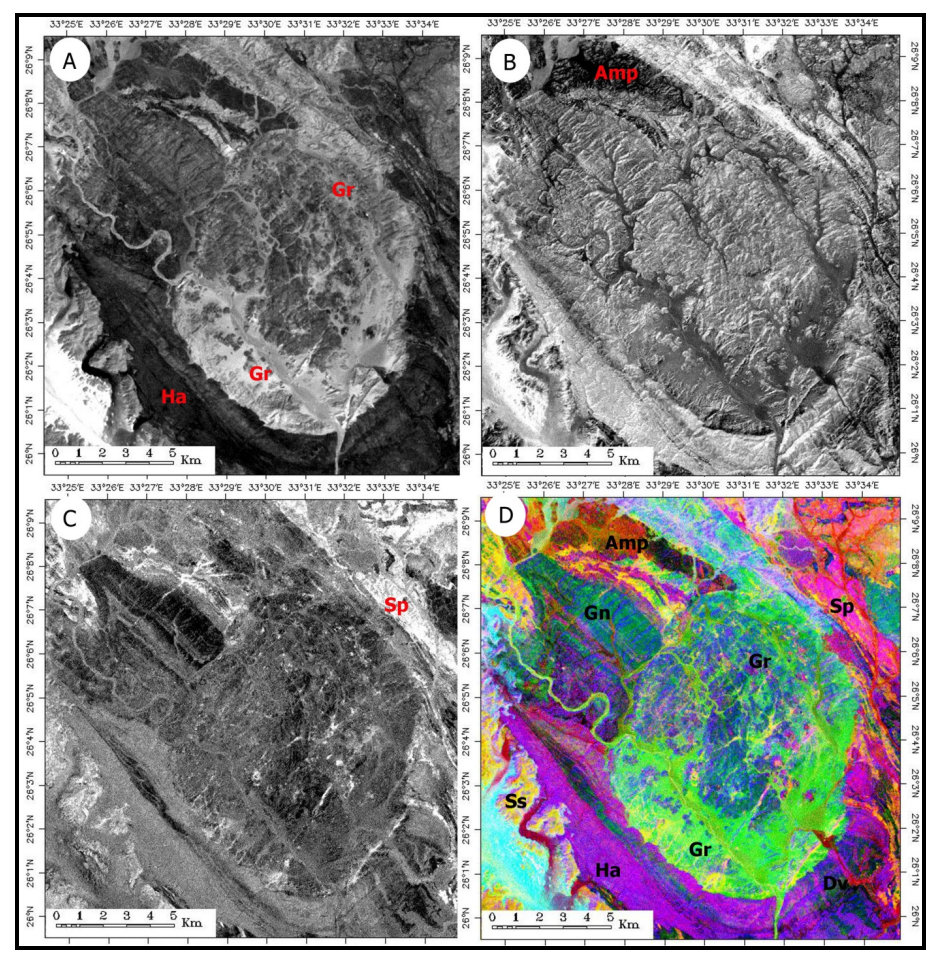

Figure 4. A) gray-scale MNF1 image shows the Hammamt sediments (Ha) with dark gray tone, B) gray-scale MNF3 image shows the amphibolites (Amp) with dark tone and felsites with bright tone, C) gray-scale MNF4 image shows the gneisses $(\mathrm{Gn})$ with dark gray tone and talc-serpentinites $(\mathrm{Sp})$ with bright tone, D) False color

RGB combination of (MNF4, MNF1, MNF3) discriminates clearly between the different rock units

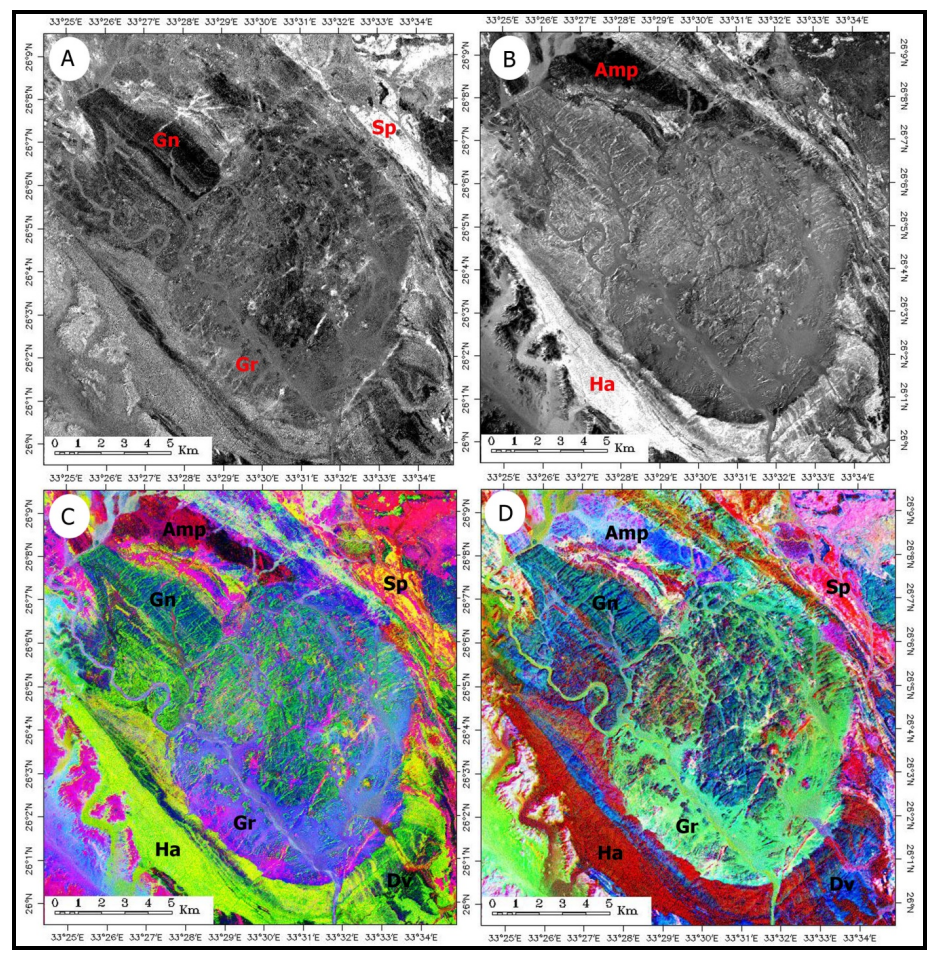

Figure 5. A) gray-scale band ratio (5/7) image shows the talc-serpentinites $(\mathrm{Sp})$ with bright tone and gneissose rocks $(\mathrm{Gn})$ with dark gray tone, B) gray-scale band ratio (4/5) image shows the amphibolites (Amp) with dark tone and Hammamat sediments (Ha) with bright tone, C) FCC band ratio $(5 / 7,4 / 5,3 / 1)$ image, and D) FCC band ratio $(5 / 7,5 / 1,5 / 4 * 3 / 4)$ image are clearly able to discriminate all the rock units of ophiolitic mélange, granitic rocks, gneisses, Hammamat sediments, Dokhan volcanics and felsites of Um Had area 


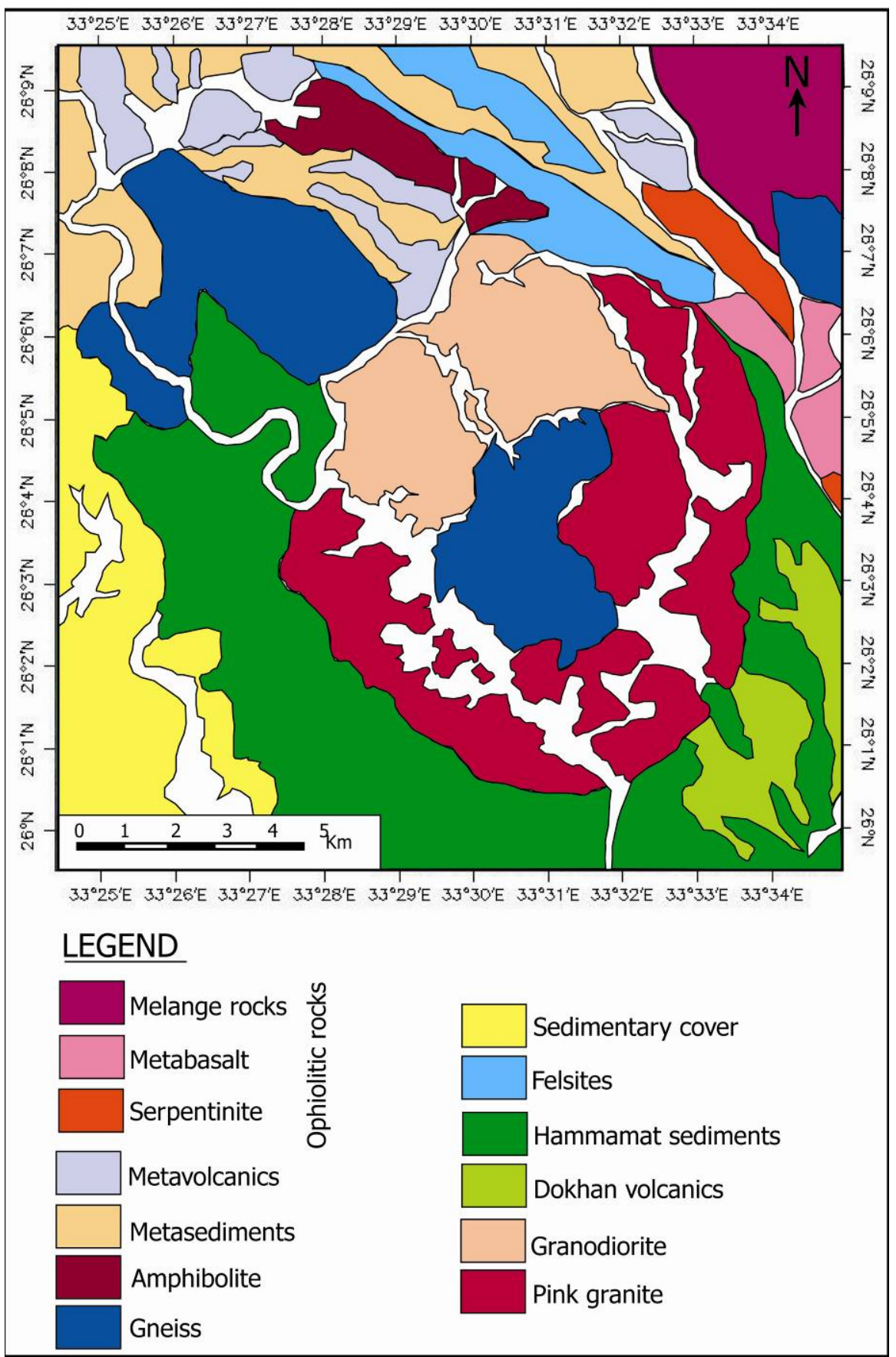

Figure 6. Detailed lithologic map of Um Had area, generated from the processed ETM+ data

\section{Conclusions}

Space-borne data processing techniques enable the rapid and inexpensive mapping of surface geological and mineralogical features. This capability proves highly useful when working on arid areas. In this study, several enhancements of Landsat Enhanced Thematic Mapper plus (i.e., band ratios, false colour composites and principal component analysis) were used and evaluated to obtain the best possible visualisation the various lithological units underlying the Um Had area, Central Eastern Desert of Egypt. The resulting gray-scale PC2, PC3 and PC4 images are best to clearly discriminate the Hammamat sediments, amphibolites and talcserpentinites, respectively. The MNF3 and MNF4 images are found able to discriminate the felsites and talcserpentinites, respectively. The band ratio $5 / 7$ and $4 / 5$ images are able to delineate the talc-serpentinites and Hammamat sediments, respectively. Information collected from gray-scale and false color composite images led to generation of a new comprehensive geological map of the study area. This work demonstrates the usefulness 
of multispectral imagery in the lithological mapping and establishes a full remote sensing procedure, which can be applied to a wider region in arid environments.

\section{Acknowledgements}

I would express deep thanks and gratitude to Dr. Ashraf Emam (Aswan Univ., Egypt) and Dr. Basem Zoheir (Benha Univ., Egypt) for their immense help in undertaking this work, and for making the remote sensing data and software available.

\section{References}

Abdel-Rahman, A. F. M., \& Doig, R. (1987). The Rb-Sr geochronological evolution of the Ras Gharib segment of the northern Nubian Shield. Journal of the Geological Society, 144(4), 577-586. http://dx.doi.org/10.1144/gsjgs.144.4.0577

Abdelsalam, M. G., \& Stern, R. J. (1999). Mineral exploration with satellite remote sensing imagery: Examples from the Neoproterozoic Arabian-Nubian Shield. Journal of African Earth Sciences, 28(4), 1.

Abou Elmagd, K., Emam, A., \& Ali-Bik, M. W. (2013). Chemostratigraphy, petrography and remote sensing characterization of the Middle Miocene - Holocene sediments of Ras Banas Peninsula, Red Sea Coast, Egypt. Carpathian Journal of Earth and Environmental Sciences, 8(3), 27-42.

Abrams, M., \& Hook, S. J. (1995). Simulated ASTER data for geologic studies. Geoscience and Remote Sensing, IEEE Transactions on, 33(3), 692-699. http://dx.doi.org/10.1109/36.387584

Abrams, M. J., Rothery, D. A., \& Pontual, A. (1988). Mapping in the Oman ophiolite using enhanced Landsat $\begin{array}{lllll}\text { Thematic Mapper } & \text { images. }\end{array}$ http://dx.doi.org/10.1016/0040-1951(88)90254-5

Ali-Bik, M. W., Taman, Z., El Kalioubi, B., \& Abdel Wahab, W. (2012). Serpentinite-hosted talc-magnesite deposits of Wadi Barramiya area, Eastern Desert, Egypt: Characteristics, petrogenesis and evolution. Journal of African Earth Sciences, 64, 77-89. http://dx.doi.org/10.1016/j.jafrearsci.2011.11.002

Black, R., \& Liegeois, J. P. (1993). Cratons, mobile belts, alkaline rocks and continental lithospheric mantle: the Pan-African testimony. Journal of the Geological Society, 150(1), 89-98. http://dx.doi.org/10.1144/gsjgs.150.1.0088

Boardman, J. W., \& Kruse, F. A. (1994). Automated spectral analysis: a geological example using AVIRIS data, north Grapevine Mountains, Nevada. In Proceedings of the Thematic Conference on Geologic Remote Sensing (Vol. 1, pp. I-407). Environmental Research Institute of Michigan.

Breitkreuz, C., Eliwa, H., Khalaf, I., Gameel, K. E., Bühler, B., Sergeev, S., ... Murata, M. (2010). Neoproterozoic SHRIMP U-Pb zircon ages of silica-rich Dokhan volcanics in the North Eastern Desert, Egypt. Precambrian Research, 182(3), 163-174. http://dx.doi.org/10.1016/j.precamres.2010.06.019

CHAVEZ, P. T., \& Kwarteng, A. Y. (1989). Extracting spectral contrast in Landsat Thematic Mapper image data using selective principal component analysis. Photogrammetric Engineering and Remote Sensing, 55(3), 339-348.

Crane, R. B. (1971). Preprocessing techniques to reduce atmospheric and sensor variability in multispectral scanner data. Proceedings of the 7th International Symposium on Remote Sensing of Environment Ann Arbor Michigan, 2, 345-1355.

Dogan, H. M. (2008). Applications of remote sensing and Geographic Information Systems to assess ferrous minerals and iron oxide of Tokat province in Turkey. International Journal of Remote Sensing, 29(1), 221-233. http://dx.doi.org/10.1080/01431160701269010

Drury, S. A. (1987). Image interpretation in geology (p. 243). London: Allen \& Unwin. http://dx.doi.org/10.1007/978-94-010-9393-4

Drury, S. A. (1993). Image interpretation in geology (p. 283). London: Chapman and Hall.

Engel, A. E. J., Dixon, T. H., \& Stern, R. J. (1980). Late Precambrian evolution of Afro-Arabian crust from ocean arc to craton. Geological Society of America Bulletin, 91(12), 699-706. $\mathrm{http}: / / \mathrm{dx}$. doi.org/10.1130/0016-7606(1980)91<699:LPEOAC $>2.0 . C O ; 2$

Fowler, T. J. (2001). Pan-African granite emplacement mechanisms in the Eastern Desert, Egypt. Journal of African Earth Sciences, 32(1), 61-86. http://dx.doi.org/10.1016/S0899-5362(01)90019-3

Frei, M., \& Jutz, S. (1990). Use of Thematic Mapper data for the detection of gold bearing formations in the 
Eastern Desert of Egypt. In Thematic Conference on Remote Sensing for Exploration Geology-Methods, Integration, Solutions, 7 th, Calgary, Canada (pp. 1157-1172).

Gad, S. (2002). Exploration for mineralized granites in Central Eastern Desert, Egypt (Master's Thesis). Faculty of Science, Aswan, South Valley University, Egypt.

Gad, S., \& Kusky, T. (2006). Lithological mapping in the Eastern Desert of Egypt, the Barramiya area, using Landsat thematic mapper (TM). Journal of African Earth Sciences, 44(2), 196-202. http://dx.doi.org/10.1016/j.jafrearsci.2005.10.014

Gad, S., \& Kusky, T. (2007). ASTER spectral ratioing for lithological mapping in the Arabian-Nubian shield, the Neoproterozoic Wadi Kid area, Sinai, Egypt. Gondwana Research, 11(3), 326-335. http://dx.doi.org/10.1016/j.gr.2006.02.010

Green, A. A., Berman, M., Switzer, P., \& Craig, M. D. (1988). A transformation for ordering multispectral data in terms of image quality with implications for noise removal. Geoscience and Remote Sensing, IEEE Transactions on, 26(1), 65-74. http://dx.doi.org/10.1109/36.3001

Gupta, R. P. (1991). Remote Sensing Geology (p. 356). Berlin-Heidelberg (Springer). http://dx.doi.org/10.1007/978-3-662-12914-2

Gupta, R. P. (2003). Remote Sensing Geology (p. 655). Springer, Heidelberg. http://dx.doi.org/10.1007/978-3-662-05283-9

Hashad, A. H. (1980). Present status of geochronological data on the Egyptian basement complex. Bull Inst. Appl. Geol. (Jeddah), 3, 31-46. http://dx.doi.org/10.1016/B978-0-08-024479-2.50007-9

Johnson, P. R., \& Woldehaimanot, B. (2003). Development of the Arabian-Nubian Shield: perspectives on accretion and deformation in the northern East African Orogen and the assembly of Gondwana. Geological Society, London, Special Publications, 206(1), 289-325. http://dx.doi.org/10.1144/GSL.SP.2003.206.01.15

Kaufmann, H. (1988). Mineral exploration along the Aqaba-Levant Structure by use of TM-data. Concepts, processing and results. International Journal of Remote Sensing, 9(10-11), 1639-1658. http://dx.doi.org/10.1080/01431168808954966

Kröner, A., Todt, W., Hussein, I. M., Mansour, M., \& Rashwan, A. (1992). Dating of late Proterozoic ophiolites in Egypt and the Sudan using the single grain zircon evaporation technique. Precambrian Research, 59(1), 15-32. http://dx.doi.org/10.1016/0301-9268(92)90049-T

Kusky, T. M., Abdelsalam, M., Tucker, R. D., \& Stern, R. J. (2003). Evolution of the East African and related orogens, and the assembly of Gondwana. Precambrian Research, 123(2), 81-85. http://dx.doi.org/10.1016/S0301-9268(03)00062-7

Kusky, T. M., \& Ramadan, T. M. (2002). Structural controls on Neoproterozoic mineralization in the South Eastern Desert, Egypt: an integrated field, Landsat TM, and SIR-C/X SAR approach. Journal of African Earth Sciences, 35(1), 107-121. http://dx.doi.org/10.1016/S0899-5362(02)00029-5

Madani, A. A. (2009). Utilization of Landsat ETM+ data for mapping gossans and iron rich zones exposed at Bahrah area, Western Arabian Shield, Saudi Arabia. Journal of King Abdulaziz University: Earth Sciences, 20, 25-49.

Madani, A., Abdel Rahman, E. M., Fawzy, K. M., \& Emam, A. (2003). Mapping of the Hydrothermal Alteration Zones at Haimur Gold Mine Area, South Eastern Desert, Egypt Using Remote Sensing Techniques. The Egyptian Journal of Remote Sensing \& Space Sciences, 6, 47-60.

Madani, A. A., \& Emam, A. A. (2011). SWIR ASTER band ratios for lithological mapping and mineral exploration: a case study from El Hudi area, southeastern desert, Egypt. Arabian Journal of Geosciences, 4(1-2), 45-52. http://dx.doi.org/10.1007/s12517-009-0059-8

Mars, J.C., \& Rowan, L.C. (2006). Regional mapping of phyllic- and argillic-altered rocks in the Zagros magmatic arc, Iran, using Advanced Spaceborne Thermal Emission and Reflection Radiometer (ASTER) data and logical operator algorithms. Geosphere, 2, 161-186. http://dx.doi.org/10.1130/GES00044.1

Moghazi, A. K. M. (1999). Magma source and evolution of Late Neoproterozoic granitoids in the Gabal El-Urf area, Eastern Desert, Egypt: geochemical and $\mathrm{Sr}-\mathrm{Nd}$ isotopic constraints. Geological Magazine, 136(03), 285-300. http://dx.doi.org/10.1017/S0016756899002563

Moik, J. G. (1980). Digital Processing of Remotely Sensed Images. NASA SP-431. NASA Special Publication, 
431.

Moussa, E. M., Stern, R. J., Manton, W. I., \& Ali, K. A. (2008). SHRIMP zircon dating and Sm/Nd isotopic investigations of Neoproterozoic granitoids, Eastern Desert, Egypt. Precambrian Research, 160(3), 341-356. http://dx.doi.org/10.1016/j.precamres.2007.08.006

Rajesh, H. M. (2008). Mapping Proterozoic unconformity-related uranium deposits in the Rockhole area, Northern Territory, Australia using Landsat ETM+. Ore Geology Reviews, 33(3), $382-396$. http://dx.doi.org/10.1016/j.oregeorev.2007.02.003

Ramadan, T. M., \& Kontny, A. (2004). Mineralogical and structural characterization of alteration zones detected by orbital remote sensing at Shalatein District, SE Desert, Egypt. Journal of African Earth Sciences, 40(1), 89-99. http://dx.doi.org/10.1016/j.jafrearsci.2004.06.003

Rawashdeh, S. A., Saleh, B., \& Hamzah, M. (2006). The use of remote sensing technology in geological investigation and mineral detection in El Azraq-Jordan. Cybergeo: European Journal of Geography.

Sabins, F. (1997). Remote Sensing (p. 494). Principles and Interpretation.

Sabins, F. F. (1999). Remote sensing for mineral exploration. Ore Geology Reviews, 14(3), $157-183$. http://dx.doi.org/10.1016/S0169-1368(99)00007-4

Salem, S. M., Arafa, S. A., Ramadan, T. M., \& El Sayed, A. (2013). Exploration of copper deposits in Wadi El Regeita area, Southern Sinai, Egypt, with contribution of remote sensing and geophysical data. Arabian Journal of Geosciences, 6(2), 321-335. http://dx.doi.org/10.1007/s12517-011-0346-z

Shalaby, M. H., Bishta, A. Z., Roz, M. E., \& El Zalaky, M. A. (2010). Integration of Geologic and Remote Sensing Studies for the Discovery of Uranium Mineralization in Some Granite Plutons, Eastern Desert, Egypt. Journal of King Abdulaziz University: Earth Sciences, 21(1).

Singh, A., \& Harrison, A. (1985). Standardized principal components. International Journal of Remote Sensing, 6(6), 883-896. http://dx.doi.org/10.1080/01431168508948511

Stern, R. J. (1981). Petrogenesis and tectonic setting of Late Precambrian ensimatic volcanic rocks, Central Eastern Desert of Egypt. Precambrian Research, 16(3), $195-230$. http://dx.doi.org/10.1016/0301-9268(81)90013-9

Stern, R. J. (1994). Arc-assembly and continental collision in the Neoproterozoic African orogen: implications for the consolidation of Gondwanaland. Annual Review of Earth and Planetary Sciences, 22, 319-351. http://dx.doi.org/10.1146/annurev.ea.22.050194.001535

Stern, R. J., \& Gottfried, D. (1986). Petrogenesis of a late Precambrian (575-600 Ma) bimodal suite in northeast Africa. Contributions to Mineralogy and Petrology, 92(4), 492-501. http://dx.doi.org/10.1007/BF00374431

Stern, R. J., \& Hedge, C. E. (1985). Geochronologic and isotopic constraints on Late Precambrian crustal evolution in the Eastern Desert of Egypt. Ann. J. Sci, 285, 97-127.

Sultan, M., Arvidson, R. E., \& Sturchio, N. C. (1986). Mapping of serpentinites in the Eastern Desert of Egypt by using Landsat thematic mapper data. Geology, 14(12), 995-999. http://dx.doi.org/10.1130/0091-7613(1986)14<995:MOSITE>2.0.CO;2

Sultan, M., Arvidson, R. E., Sturchio, N. C., \& Guinness, E. A. (1987). Lithologic mapping in arid regions with Landsat thematic mapper data: Meatiq dome, Egypt. Geological Society of America Bulletin, 99(6), 748-762. http://dx.doi.org/10.1130/0016-7606(1987)99<748:LMIARW>2.0.CO;2

Wilde, S., \& Youssef, K. (2002). A re-evaluation of the origin and setting of the Late Precambrian Hammamat Group based on SHRIMP U-Pb dating of detrital zircons from Gebel Umm Tawat, North Eastern Desert, Egypt. Journal of the Geological Society, 159(5), 595-604. http://dx.doi.org/10.1144/0016-764901-081

Wilde, S. A., \& Youssef, K. (2000). Significance of SHRIMP U-Pb dating of the Imperial Porphyry and associated Dokhan Volcanics, Gebel Dokhan, north Eastern Desert, Egypt. Journal of African Earth Sciences, 31(2), 403-413. http://dx.doi.org/10.1016/S0899-5362(00)00096-8

Willis, K. M., Stern, R. J., \& Clauer, N. (1988). Age and geochemistry of Late Precambrian sediments of the Hammamat Series from the Northeastern Desert of Egypt. Precambrian Research, 42(1), 173-187. http://dx.doi.org/10.1016/0301-9268(88)90016-2

Youssef, A. M., Hassan, A. M., \& Mohamed, M. A. E. M. (2009). Integration of remote sensing data with the field and laboratory investigation for lithological mapping of granitic phases: Kadabora pluton, Eastern 
Desert, Egypt. Arabian Journal of Geosciences, 2(1), 69-82. http://dx.doi.org/10.1007/s12517-008-0020-2

Zoheir, B., \& Emam, A. (2012). Integrating geologic and satellite imagery data for high-resolution mapping and gold exploration targets in the South Eastern Desert, Egypt. Journal of African Earth Sciences, 66, 22-34. http://dx.doi.org/10.1016/j.jafrearsci.2012.02.007

Zoheir, B., \& Emam, A. (2013). Field and ASTER imagery data for the setting of gold mineralization in Western Allaqi-Heiani belt, Egypt: A case study from the Haimur deposit. Journal of African Earth Sciences. http://dx.doi.org/10.1016/j.jafrearsci.2013.06.006

\section{Copyrights}

Copyright for this article is retained by the author(s), with first publication rights granted to the journal.

This is an open-access article distributed under the terms and conditions of the Creative Commons Attribution license (http://creativecommons.org/licenses/by/3.0/). 